\title{
INDUSTRI PERBANKAN YANG TERKONSENTRASI APAKAH TETAP DAPAT BERKOMPETISI? KASUS PERBANKAN SYARIAH
}

\author{
Sancoko $^{1 *}$ \\ 'Program Studi Administrasi Perkantoran dan Sekretari Program Vokasi Universitas Indonesia
}

\begin{abstract}
ABSTRAK - Tulisan ini membahas tentang kondisi kompetisi pada industri perbankan di Indonesia, khususnya entitas Bank Syariah. Pemilihan Bank syariah menjadi objek penelitian karena secara kuantitatif mengalami pertumbuhan yang signifikan. Penelitian ini menggunakan pendekatan kuantitatif dengan desain deskriptif. Sumber data yang digunakan berasal dari laporan tahunan individual Bank di situs Bank Indonesia sejak periode 2008-2011. Untuk mengukur aspek kompetisi antar Perbankan Syariah menggunakan metode Panzar \& Rosestatistic. Berdasarkan hasil penelitian didapatkan hasil bahwa perbankan syariah masuk ke dalam struktur pasar monopolistic competitition.
\end{abstract}

Kata kunci:

ABSTRACT -This paperdiscusses theconditions ofcompetitionbankingindustryin Indonesia, especiallyIslamic Bankingentity. Islamic Bankbecame the objectof research because significant growth in industrial banking.This studyuses a quantitative approachwith adescriptivedesign. Source ofdata used fromindividualbank's annual reporton the websiteof BankIndonesia fromthe period 2008-2011. Tomeasureaspects ofcompetition Islamic Bankingusing PanzarERRosestatisticmethods. Results of studyshowed thatIslamic banking came into condition of monopolisticcompetitition structure.

Keywords:

\section{PENDAHULUAN}

\section{Latar Belakang}

Bank Syariah adalah Bank yang prinsip dasar operasional tidak mengenal konsep bunga. Transaksi keuangan syariah menggunakan konsep kemitraan/kerjasama (mudharabah dan musyarakah) dengan prinsip bagi hasil. Bank Islam adalah bank yang beroperasi dengan prinsip syariah Islam dan bank yang tata cara beroperasinya mengacu kepada ketentuan-ketentuan Al-Qur'an dan Hadits, khususnya yang menyangkut tata cara bermuamalat secara Islam. Ekonomi Islam berbeda dari kapitalisme dan sosialisme karena Islam menentang eksploitasi oleh pemilik modal terhadap buruh yang miskin, dan melarang penumpukan kekayaan walaupun disatu sisi kepemilikan atas harta individu tetap diizinkan yang dikedepankan ialah nilai-nilai keadilan.

Dalam literature ekonomi dapat kita ketahui terdapat 4 jenis struktur pasar yaitu: Pasar persaingan sempurna, pasar monopolistik, pasar oligopoli dan pasar monopoli. Dari keempat struktur pasar itu yang paling terbaik ialah struktur pasar 
persaingan sempuna. Salah satu kelebihan pasar persaingan sempurna ialah kebebasan bertindak dan memilih. Di dalam pasar yang bebas tidak seorang pun mempunyai kekuasaan dalam menetukan harga, jumlah produksi, dan jenis-jenis barang yang diproduksikan. Begitu pula dalam menentukan bagaimana faktor-faktor produksi digunakan dalam masyarakat, efisiensilah yang menjadi faktor yang menentukan pengalokasiannya. Pasar persaingan sempurna merupakan pasar yang mendekati keadilan.

Dengan adanya kebebasan untuk memproduksikan berbagai jenis barang maka masyarakat dapat mempunyai pilihan yang lebih banyak terhadap barang-barang dan jasa yang diperlukan untuk memenuhi kebutuhannya. Lawan dari pasar persaingan sempurna ialah pasar monopoli dimana suatu industri hanya dikuasai oleh satu perusahaan saja. Persaingan di dalam struktur pasar monopoli boleh dikatakan hampir tidak ada. Dalam kegiatan usaha di Indonesia terdapat larangan melakukan monopoli, Hal ini didukung dengan dikeluarkannya UU no 5 tahun 1999 tentang anti monopoli dan persaingan usaha tidak sehat. Selain itu di Indonesia terdapatnya lembaga anti monopoli yaitu Komisi Pengawas Persaingan Usaha(KPPU).

Pada penelitian saya terdahulu (sancoko,2012) diketahui bahwa kondisi industri perbankan syariah dalam kondisi struktur pasar oligopoli yang high concentrated. Dengan metode pendekatan Concentration Ratio(CR4) penguasaan empat perusahaan utama dalam hal 3 aspek perbankan yaitu asset, kredit dan dana pihak ketiga rata-rata diatas 89 persen. Sedangkan dengan pendekatan Herfindahl Hirchman Indeks(HHI) untuk tiga aspek perbankan yang sama memiliki nilai rata-rata diatas 2900 point, hal ini menunjukkan industri perbankan syariah dalam kondisi high concentration.

\section{Permasalahan}

Apakah struktur pasar perbankan syariah yang terkonsentrasi memungkinkan terjadinya persaingan (kompetisi) dalam industri tersebut?

\section{Tinjauan Pustaka}

a. Contestable Market

Pandangan ini dikembangkan oleh William J. Baumol (1982), dalam pendekatan ini dijelaskan bahwa laba yang berlebihan akan menarik perusahaan-perusahaan baru untuk masuk pasar, hal ini disebabkan biaya masuk(Entry) yang rendah. Bentuk pasar ini dapat diistilahkan dengan pasar yang diperebutkan (Contestable Market) atau dapat digambarkan kondisi pasar dikuasai oleh satu pemain saja (dalam kondisi monopoli) namun tidak menutup terjadinya persaingan usaha. Syarat sebuah pasar dikondisikan dalam Contestable Market adalah:

1. Adanya Kebebasan untuk masuk atau keluar pasar (no entry or exit barriers)

2. Biaya sunk cost minimum

Keputusan memasuki pasar oleh sebuah produsen tidak berhubungan dengan kondisi struktur internal pasar baik pasar itu dalam 
kondisi monopoly ataupun oligopoly. Pandangan ini mengatakan bahwa kondisi "free entry" mempengaruhi langsung kinerja pasar, sebuah industri dapat saja dikuasai oleh satu atau sedikit perusahaan namun perusahaan baru yang potensial dapat masuk atau keluar dari sebuah pasar dengan cepat tanpa kehilangan modalnya atau tidak ada sunk cost. Dengan tiadanya sunk cost hal ini menyebabkan perusahaan lama(incumbent) menghadapi kondisi hit and run dalam menghadapai kondisi persaingan pasar yang ada.

Hal ini menyebabkan perusahaan baru yang potensial dapat masuk dan keluar industri dengan mudah (free entry) dan tidak harus menunggu sampai mendapat tingkat penerimaan tertentu untuk menutup sunk cost. Dalam industri yang contestable perusahaan baru yang potensial memiliki fungsi biaya yang sama dengan perusahaan lama. Untuk mengetahui perilaku persaingan yang bersifat contestable atau non contestable ini berkembanglah metode pengukuran nonstruktural seperti yang dilakukan oleh Bresnahan-Lau(1981) dan Panzar-Rose(1987). Metode non-struktural tersebut mengukur perilaku persaingan perbankan tanpa menggunakan informasi struktur pasar secara eksplisit. Pengukuran perilaku persaingan dilakukan dengan melihat perbedaan struktur biaya dari harga persaingan.

\section{Metode Penelitian}

\section{a. Jenis dan Sumber Data}

\section{i. Jenis Data}

Data yang digunakan dalam penelitian ini adalah data sekunder berupa data Panel yang bersumber dari data laporan keuangan publikasi individual bank (data uanaudited) yang berada pada situs Bank Indonesia serta situs masing-masing perusahaan bank. Data yang digunakan ialah data setiap bulan desember yang dianggap sebagai data laporan tahunan, data ini diambil sejak tahun 2008 hingga tahun 2011.

\section{ii. Sumber data}

Penelitian ini menggunakan data sekunder. Data sekunder adalah data yang diperoleh dari orang lain yang melakukan penelitian dari sumbersumber yang telah ada (Hasan, 2000).

\section{b. Metode Analisis}

\section{i. Panzar Rosse-H Statistik atau PR- H statistic}

Salah satu teknik pengukuran yang digunakan untuk mempelajari kondisi persaingan dalam industri perbankan adalah kerangka Panzar dan Rosse (1987) atau disebutan PR-H statistik. Kerangka PR-H statistik mempelajari dampak dari perubahan harga input (biaya) terhadap keseimbangan (ekuilibrium) pendapatan yang tergantung pada struktur pasar dimana bank tersebut beroperasi dalam sistem industri perbankan. Persamaan ini diturunkan dari model umum keseimbangan pasar perbankan. Dimana penentuan output keseimbangan dan keseimbangan jumlah 
bank dengan memaksimalkan keuntungan pada level bank secara individu maupun pada tingkatan industri.

Panzar \& Rose menjelaskan bahwa dalam kondisi monopoli, kenaikan harga input akan meningkatkan marginal cost mengurangi output ekuilibrium dan kemudian mengurangi pendapatan; maka $\mathrm{H}$ akan menjadi nol atau negatif (Bikker dan Haaf, 2002). Dengan kata lain, pasar di mana terdapat kekuatan monopoli akan menghasilkan hubungan negatif antara kedua variabel, karena pendapatan kotor akan bergerak berlawanan arah dari perubahan unit cost. Logika ekonominya adalah bahwa penetapan harga output monopoli tidak tergantung pada perubahan harga input.

Dalam menganalisis kondisi monopolistic competition, pendekatan Panzar \& Rose mendasarkan pada analisis statika komparatif dari model keseimbangan persaingan monopolistis Chamberlinian (Bikker dan Haaf, 2002). Dalam kasus persaingan monopolistik produk bank dianggap sebagai substitusi yang sempurna satu sama lain model Chamberlinian menghasilkan solusi kompetisi yang sempurna, karena elastisitas permintaan mendekati tak terhingga (Bikker dan Haff, 2002). Dalam pasar persaingan sempurna, peningkatan harga input akan meningkatkan rata-rata biaya secara proporsional. Keluarnya beberapa bank akan meningkatkan permintaan yang dihadapi oleh bank-bank yang tersisa, yang menyebabkan kenaikan harga dan pendapatan yang setara dengan kenaikan biaya (Bikker dan Haaf: 2002). Akhirnya, nilai $H$ di pasar persaingan sempurna adalah sama dengan satu.

Pada kasus monopolistic competition nilai $H$ statistics akan bernilai antara $\mathrm{O}$ dan 1 , $\mathrm{O}<\mathrm{H}<1$. Nilai $\mathrm{H}$ yang positif menunjukkan bahwa datanya konsisten dengan persaingan monopolistik. Meskipun bank berperilaku seperti monopolis, kondisi entry dan exit bank lain yang menawarkan persaingan produk yang tidak sempurna menjadikan mereka mendapatkan keuntungan normal. Dalam kasus monopolistic competition, bank menghasilkan output yang lebih banyak dan menerapkan harga yang lebih rendah dibandingkan kondisi monopoli murni.

Dalam merespon kenaikan harga input, bank akan menaikkan harga (baik untuk tingkat bunga pinjaman) sampai mereka bisa menutup naiknya biaya untuk tetap bertahan dalam persaingan. Selama proses ini, bank yang tidak efisien mungkin akan diakuisisi oleh bank lain atau harus keluar dari pasar. Keluarnya beberapa perusahaan meningkatkan permintaan yang dihadapi oleh bank yang masih ada, yang mengakibatkan naiknya harga dan penerimaan yang sepadan dengan naiknya biaya. Sedangkan di pasar oligopoli, nilai $H$ dapat juga bernilai positif, yakni ketika terdapat interaksi strategis antara 
Tabel 1.1

Klasifikasi H-Stat

\begin{tabular}{|l|l|}
\hline \multicolumn{2}{|c|}{ Ringkasan Kekuatan Diskrimminasi } \\
\hline Nilai $\mathbf{H}$ & \multicolumn{1}{|c|}{ Lingkungan yang kompetitif } \\
\hline $\mathrm{H} \leq 0$ & $\begin{array}{l}\text { Keseimbangan Monopoli: masing-masing bank beroperasi secara } \\
\text { independen dan maksimisasi keuntungan layaknya di bawah kondisi } \\
\text { monopoli ( } H \text { adalah fungsi menurun dari elastisitas permintaan) atau } \\
\text { kartel sempurna. }\end{array}$ \\
\hline $\mathrm{O}<\mathrm{H}<1$ & $\begin{array}{l}\text { Keseimbangan persaingan monopolistik dengan kondisi free entry }(H \\
\text { merupakan fungsi menaik dari elastisitas permintaan ). }\end{array}$ \\
\hline $\mathrm{H}=1$ & $\begin{array}{l}\text { Persaingan sempurna. Ekuilibrium free entry dengan utilisasi } \\
\text { kapasitas penuh yang efisien. }\end{array}$ \\
\hline
\end{tabular}

Sumber: Bikker Eं Haaf (2002)

\section{ii. Model yang digunakan}

Penerapan kerangka PR dalam penelitian ini memerlukan dua asumsi yang perlu diterapkan dalam. Pertama, bank diperlakukan sebagai perusahaan dengan produk tunggal yang bertindak sebagai perantara keuangan (peran intermediasi). Oleh karena itu bank menghasilkan pendapatan bunga dengan menggunakan dana, tenaga kerja dan modal fisik sebagai input (De Bandt dan Davis, 2000). Dalam penelitian ini penulis mempertimbangkan total revenue sebagai proksi dari pendapatan total (total income), hal ini didasarkan fakta bahwa Perbankan Syariah tidak menghasilkan pendapatan dari bunga. Variabel dependen dibagi oleh total aset untuk memperhitungkan perbedaan dari size bank. Kedua diasumsikan bahwa biaya input yang tinggi tidak berhubungan dengan kualitas layanan yang lebih tinggi yang menghasilkan pendapatan yang lebih tinggi (Gelos dan Roldos; 2001). Jika terdapat korelasi, mungkin ada bias dalam menafsirkan nilai $\mathrm{H}$ statistic, model operasional dari bentuk susut penerimaan yang akan diuji adalah sebagai berikut:

$$
\begin{array}{ll}
\ln \left(\mathrm{T}_{\text {Pend }}\right)= & \mathrm{C}+\alpha 1 \ln \left(\mathrm{B}_{\text {personil }}\right)+\alpha 2 \ln \left(\mathrm{B}_{\text {bunga }}\right)+\alpha 3 \ln \left(\ln \mathrm{B}_{\text {Fisik }}\right)+\alpha 4 \ln \left(\mathrm{Y}_{\text {ekuitas }}\right)+\alpha 5 \ln \\
& \left(\mathrm{Y}_{\text {Kredit }}\right)+\varepsilon_{\text {it }}
\end{array}
$$

Sumber: Ariss (2009)

Model ekonometrika ini penulis adaptasikan dari penelitian rima turk ariss (2009), dimana variabel ini terbagi menjadi 2 bagian yaitu variabel terikat 
(dependen) dan variabel independen. Semua variabel terikat dan variabel bebas dibagi dengan asset, penggunaan asset sebagai variabel pembagi berfungsi untuk mengatasi perbedaan size bank yang menjadi sampel penelitian. Variabel ini berbentuk logaritma natural (ln), variabel terikat berasal dari rasio total pendapatan terhadap total asset, keputusan untuk memasukkan total revenue sebagai proxy total pendapatan didasarkan kepada prinsip bank syariah yang tidak mengenal bunga sebagai pendapatan.

Sementara untuk variabel bebas terdiri dari dua kelompok yaitu, variabel input utama serta variabelBank Spesific
Factor (BSF) dari suatu bank. Untuk variabel input utama terdiri dari rasio beban personalia terhadap total asset, kedua adalah rasio biaya pendanaan yang diwakili oleh rasio beban bunga dibanding total deposito, yang ketiga adalah rasio beban operasional lainnya terhadap total asset.Untuk variabel bank spesifik factor terdiri dari dua bagian yaitu; Pertama, rasio dari ekuitas terhadap total asset yang berfungsi mengontrol perbedaan modal. Kedua adalah rasio kredit bersih terhadap total asset berfungsi sebagai proxy derajat tingkat intermediasi bank. Definisi operasional dari model di atas dapat dijabarkan sebagai berikut:

Tabel 1.2

Model Operasionalisasi Untuk Bank Syariah

\begin{tabular}{|c|c|c|}
\hline Variabel & Proksi & Indikator (cara perhitungan) \\
\hline ln Tpend & $\begin{array}{l}\text { Total } \\
\text { pendapatan }\end{array}$ & $\frac{\text { Pendapatan Operasional }}{\text { Total Asset }}$ \\
\hline $\ln \mathrm{B}_{\text {personil }}$ & $\begin{array}{l}\text { Biaya tenaga } \\
\text { kerja }\end{array}$ & $\frac{\text { Beban personalia }}{\text { Total Asset }}$ \\
\hline $\ln \mathrm{B}_{\text {bunga }}$ & $\begin{array}{l}\text { Biaya } \\
\text { finansial }\end{array}$ & $\begin{array}{c}\text { Bagi hasil untuk Investor Dana Investasi Tidak Terikat } \\
\text { Dana Pihak ketiga }\end{array}$ \\
\hline $\ln B_{\text {Fisik }}$ & $\begin{array}{l}\text { Biaya modal } \\
\text { fisik }\end{array}$ & $\frac{\text { Beban Operasional lainnya- beban personalia }}{\text { Total Aset }}$ \\
\hline $\ln Y_{\text {ekuitas }}$ & $\begin{array}{l}\text { Perbedaan } \\
\text { modal }\end{array}$ & $\frac{\text { Ekuitas }}{\text { Total Aset }}$ \\
\hline $\ln Y_{\text {Kredit }}$ & Intermediasi & $\underline{\text { Kredit }}$ \\
\hline
\end{tabular}

\section{HASIL DAN PEMBAHASAN}

\section{Variabel Utama Bank Syariah}

Untuk menentukan kondisi kompetisi pasar industri Perbankan Syariah pada periode 2008- 2011 berdasarkan nilai H-stat, dimana nilai $H$-stat merupakan penjumlahan dari nilai koefisien $\alpha 1\left(B_{\text {personil }}\right)+\alpha 2\left(B_{\text {bunga }}\right)+$

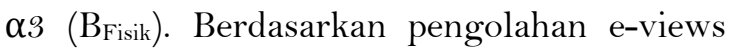
didapatkan nilai $\mathrm{H}$ stat bank syariah pada tabel berikut: 
Tabel 1.3

Nilai H-Stat Bank Syariah

\begin{tabular}{|l|l|l|l|}
\hline Variabel & Nilai & Prob & Sig \\
\hline $\ln \mathrm{B}_{\text {personil }}$ & 0.480579 & 0.0000 & $* * *$ \\
\hline $\ln \mathrm{B}_{\text {bunga }}$ & 0.256467 & 0.0042 & $* * *$ \\
\hline $\ln \mathrm{B}_{\text {Fisik }}$ & -0.025947 & 0.6298 & \\
\hline $\ln \mathrm{Y}_{\text {ekuitas }}$ & -0.103688 & 0.0059 & $* * *$ \\
\hline $\ln \mathrm{Y}_{\text {Kredit }}$ & -0.040934 & 0.2570 & \\
\hline R-squared & 0.921608 & & \\
\hline H-stat & 0.737046 & & \\
\hline
\end{tabular}

Sumber: data diolah

****Nilai sig ditingkat $1 \%$

Berdasarkan tabel diatas dapat diketahui nilai $\mathrm{H}$-stat yang berasal dari penjumlahan $\alpha 1$ $\left(\mathrm{B}_{\text {personil }}\right)+\alpha 2$ ( $\left.\mathrm{B}_{\text {bunga }}\right)+\alpha 3\left(\mathrm{~B}_{\text {Fisik }}\right)$ sebagai input utama Perbankan Syariah senilai 0.737046. Untuk nilai beban fisik tidak dimasukkan kedalam perhitungan karena secara nilai tidak signifikan secara statistik. Dari ketiga variabel input tersebut nilai terbesar berasal dari variabel beban personil. Nilai koefisien beban personil sebesar 0.480579. Hal ini berarti bahwa peningkatan sebesar $10 \%$ pada variabel beban personil maka akan meningkatkan pendapatan bank syariah sebesar 4.80 persen. Peningkatan koefisien biaya personalia sejalan dan sebagai konsekuensi logis meningkatnya jumlah bank syariah yang baru.

Pada Cetak Biru Perbankan Syariah Nasional 2010-2015 dijelaskan bahwa pengembangan human capital merupakan salah satu pilar penting dari enam pilar strategis pengembangan perbankan syariah nasional. Di samping itu tumbuh pesatnya industri perbankan syariah dari sisi jumlah bank, jaringan kantor maupun meningkatnya volume usaha dan ragam produk perbankan syariah menuntut tersedianya sumberdaya manusia dalam kuantitas dan kualitas yang semakin meningkat. Perbandingan jumlah perkembangan asset dan perkembangan sumber daya manusia (SDM) dapat dilihat pada grafik berikut:

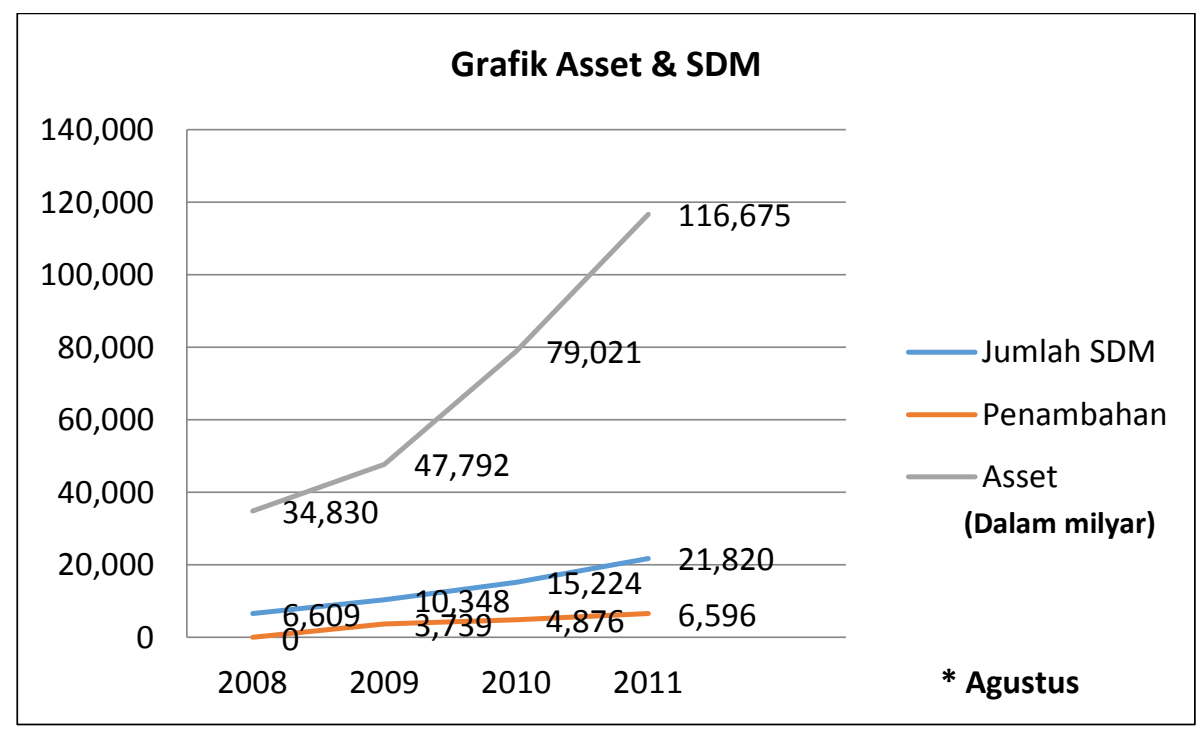

Sumber: Statistik Perbankan Syariah 2012 diolah

Gambar 1.1

Perbandingan Asset dengan SDM Bank Syariah 
Berdasarkan gambar diatas terlihat pada tahun 2008 berjumlah jumlah SDM yang bekerja di perbankan syariah 6.609 orang, kemudian pada akhir desember 2011 berjumlah 21.820 orang. Hal ini menunjukan terjadinya kenaikan jumlah sumber daya manusia sebesar 246 persen. Jumlah bank umum syariah dalam 5 tahun terakhir meningkat dari 5 bank menjadi 11 bank, dan kantor bank syariah dalam 5 tahun terakhir meningkat rata-rata $24,5 \%$ pertahun. Secara kuantitas tentu saja bank membutuhkan sumberdaya insani untuk memenuhi kebutuhan diberbagai posisi dan jabatan. Berdasarkan data diatas secara rata-rata perorang SDM bank syariah pada akhir tahun 2011 di perbankan syariah mengelola asset sebesar Rp 5.35 milyar.

Peningkatan kompleksitas dan persaingan usaha ini menuntut semakin tingginya kualifikasi dan keahlian pada bidang-bidang yang masuk dalam "pekerjaan strategis" seperti untuk fungsi manajemen risiko, treasury, pengembangan produk, marketing, IT dan sebagainya. SDM yang dicari dan dibutuhkan oleh bank syariah adalah SDM yang lebih dari sekedar bankir, SDM yang multi dimensi, yang memiliki kompetensi lintas keilmuan. Ia harus memiliki kompetensi sebagai seorang ahli investasi, sekaligus ahli keuangan dan perbankan, beretika serta memahami sharia compliance.

Sumbangan terbesar kedua berasal dari rasio beban bagi hasil (bunga $=$ konvensional) dibanding dana pihak ketiga (DPK) yang memiliki nilai koefisien sebesar 0.256467. Hal ini dapat diartikan bahwa peningkatan sebesar 10 persen pada beban bagi hasil akan meningkatkan pendapatan bank syariah sebesar 2.56 persen. Dengan memiliki dana pihak ketiga yang besar, maka kapasitas pembiayaan dari perbankan syariah menjadi lebih tinggi. Sehingga perbankan dapat memberikan pembiayaan (tidak hanya kredit) lebih besar kepada pihak yang membutuhkan. Dengan melakukan pembiayaan yang lebih besar akan dapat menghasilkan pendapatan yang lebih besar bagi bank syariah.

Sedangkan untuk nilai variabel beban fisik bernilai negative sebesar -0.032861 dan tidak signifikan secara statistik. Hal ini menunjukkan penggunaan beban fisik belum dapat menghasilkan pendapatan yang lebih besar bagi perbankan syariah. Pengeluaran perbankan syariah untuk peningkatan infrastruktur perbankan dan pengeluaran dalam bentuk promosi iklan belum diperlukan dalam meningkatkan variabel pendapatan. Berbeda dengan bank konvensional yang lebih besar secara kuantitas karena perbankan konvensional memiliki cakupan wilayah operasional dan layanan yang diberikan kepada konsumen lebih luas. Hal ini berimplikasi semakin besarnya beban fisik yang diperlukan oleh perbankan konvensional.

\section{Variabel Bank Spesific Factor Perbankan Syariah}

Dari tabel diatas dua variabel bank spesifik faktor yang terdiri dari ekuitas serta kredit memiliki nilai koefisien yang negatif. 
Dimana nilai variabel ekuitas signifikan secara statistik namun mempunyai nilai yang berbanding terbalik (nilai yang negatif) yaitu sebesar -0.103688. Hal ini menjelaskan bahwa pertumbuhan ekuitas yang besar tidak dapat digunakan secara maksimal oleh perbankan syariah untuk mendapatkan keuntungan. Pertumbuhan modal yang besar di perbankan syariah tidak secara mutlak akan mendapatkan pendapatan yang besar pula. Data perubahan tingkat pendapatan, ekuitas dan kredit untuk perbankan syariah dapat dilihat pada tabel berikut ini:

Tabel 1.4

Data Perubahan pendapatan, ekuitas \& kredit

(Rp. Juta)

\begin{tabular}{|c|r|c|c|r|c|c|}
\hline Tahun & Pendapatan & $\mathbf{\%}$ & Ekuitas & \multicolumn{1}{c|}{$\%$} & \multicolumn{1}{c|}{ Kredit } & $\%$ \\
\hline Tahun 2008 & $634,337.00$ & $0.00 \%$ & $2,994,238.00$ & $0.00 \%$ & $10,515,311.00$ & $0.00 \%$ \\
\hline Tahun 2009 & $578,336.00$ & $-8.83 \%$ & $3,418,259.00$ & $14.16 \%$ & $12,742,186.00$ & $21.18 \%$ \\
\hline Tahun 2010 & $966,570.00$ & $67.13 \%$ & $8,287,653.00$ & $142.45 \%$ & $19,484,009.00$ & $52.91 \%$ \\
\hline Tahun 2011 & $1,484,610.00$ & $53.60 \%$ & $10,251,203.00$ & $23.69 \%$ & $24,318,551.00$ & $24.81 \%$ \\
\hline
\end{tabular}

Sumber: diolah

Berdasarkan data tabel perubahan terhadap pendapatan sebelum pajak, ekuitas dan kredit menunjukkan bahwa secara kuantitas jumlah ekuitas serta jumlah pembiayaan selalu bertambah dari tahun ketahun. Pertumbuhan ini tidak diiringi dengan pendapatan yang selalu meningkat. Berdasarkan tabel diatas diketahui bahwa pada tahun 2009 dimana ekuitas, net loan bertambah sebesar 14,16 persen dan 21.18 persen justru pendapatan perbankan syariah mengalami penurunan pendapatan bersih sebesar -8.83 persen. Penulis melihat turunnya jumlah pendapatan industri perbankan syariah ini disebabkan masuknya bank-bank baru ke industri perbankan syariah bukanlah bank yang mempunyai tingkat pendapatan bersih yang baik seperti bank panin syariah. Untuk nilai variabel pembiayaan (kredit) memiliki nilai yang negative yaitu sebesar -0.040934 dan tidak signifikan secara statistik. Komposisi pembiayaan (kredit) dalam perbankan syariah dapat dilihat pada tabel berikut:

Tabel 1.5

Komposisi Pembiayaan pada Perbankan Syariah di Indonesia

(Rp juta)

\begin{tabular}{|l|c|c|c|c|c|c|c|}
\hline \multicolumn{1}{|c|}{ Pembiayaan } & $\mathbf{2 0 0 5}$ & $\mathbf{2 0 0 6}$ & $\mathbf{2 0 0 7}$ & $\mathbf{2 0 0 8}$ & $\mathbf{2 0 0 9}$ & $\mathbf{2 0 1 0}$ & $\mathbf{2 0 1 1}$ \\
\hline Mudharabah & 3,124 & 4,062 & 5,578 & 6,205 & 6,597 & 8,631 & 10,229 \\
\hline Kontribusi $(\%)$ & $20.51 \%$ & $19.87 \%$ & $19.96 \%$ & $16.25 \%$ & $14.07 \%$ & $12.66 \%$ & $9.96 \%$ \\
\hline Musyarakah & 1,898 & 2,335 & 4,406 & 7,411 & 10,412 & 14,624 & 18,960 \\
\hline
\end{tabular}




\begin{tabular}{|l|c|c|c|c|c|c|c|}
\hline \multicolumn{1}{|c|}{ Pembiayaan } & $\mathbf{2 0 0 5}$ & $\mathbf{2 0 0 6}$ & $\mathbf{2 0 0 7}$ & $\mathbf{2 0 0 8}$ & $\mathbf{2 0 0 9}$ & $\mathbf{2 0 1 0}$ & $\mathbf{2 0 1 1}$ \\
\hline Kontribusi (\%) & $12.46 \%$ & $11.42 \%$ & $15.77 \%$ & $19.40 \%$ & $22.21 \%$ & $21.45 \%$ & $18.47 \%$ \\
\hline Murabahah & 9,487 & 12,624 & 16,553 & 22,486 & 26,321 & 37,508 & 56,365 \\
\hline Kontribusi (\%) & $62.28 \%$ & $61.75 \%$ & $59.24 \%$ & $58.87 \%$ & $56.14 \%$ & $55.01 \%$ & $54.91 \%$ \\
\hline Salam & 0 & 0 & 0 & 0 & 0 & 0 & 0 \\
\hline Kontribusi (\%) & 0 & 0 & 0 & 0 & 0 & 0 & \\
\hline Istishna & 282 & 337 & 351 & 369 & 423 & 347 & 326 \\
\hline Kontribusi (\%) & $1.85 \%$ & $1.65 \%$ & $1.26 \%$ & $0.97 \%$ & $0.90 \%$ & $0.51 \%$ & $0.32 \%$ \\
\hline Ijarah & 316 & 836 & 516 & 765 & 1,305 & 2,341 & 3,839 \\
\hline Kontribusi (\%) & $2.07 \%$ & $4.09 \%$ & $1.85 \%$ & $2.00 \%$ & $2.78 \%$ & $3.43 \%$ & $3.74 \%$ \\
\hline Qardh & 125 & 250 & 540 & 959 & 1,829 & 4,731 & 12,937 \\
\hline Kontribusi (\%) & $0.82 \%$ & $1.22 \%$ & $1.93 \%$ & $2.51 \%$ & $3.90 \%$ & $6.94 \%$ & $12.60 \%$ \\
\hline Total & 15,232 & 20,444 & 27,944 & 38,195 & 46,887 & 68,182 & 102,656 \\
\hline
\end{tabular}

Sumber: Statistik Perbankan Syariah 2013 diolah

Berdasarkan hasil tabel diatas di ketahui bahwa komposisi pembiayaan masih di dominasi pembiayaan yang mempunyai akad murabahah. Akad murabahah merupakan pembiayaan berupa transaksi jual beli suatu barang sebesar harga perolehan barang ditambah dengan margin yang disepakati oleh para pihak, dimana penjual menginformasikan terlebih dahulu harga perolehan kepada pembeli. Dimana secara rata-rata nilai untuk transaksi ini mencapai 58.31 persen, lebih dari separuh kegiatan pembiayaan menggunakan transaksi ini. Padahal sejatinya kegiatan akad mudarabah dan musyarakah dalam perbankan syariah merupakan cerminan dari ekonomi Islam yang menjunjung keadilan, dimana istilah untung dan rugi ditanggung bersama (profit and loss sharing) berlaku.

Dalam beberapa kajian keagamaan pembiayaan jual beli (akad murabahah) ini diperbincangkan kehalalannya. Andriansyah (2009) menjelaskan dimana sebagian ulama berpendapat bahwa akad ini bukanlah akad jual beli melainkan hilah untuk mengambil riba. Selain itu ada pula anggapan bahwa akad ini merupakancontoh dari bay'al-ma'dûm atau jual beli yang tidak ada objeknya, atau akad ini dianggap sebagai bay'atani al-bay'ah atau dua kali akad jual beli padasatu barang. Dimana secara fikih hal ini merupakan suatu kegiatan yang haram dikerjakan.Berdasarkan nilai $\mathrm{H}$-stat diatas didapatkan nilai $\mathrm{H}$-stat perbankan syariah sebesar 0.737046. Berdasarkan hasil perhitungan itu bentuk pasar perbankan syariah masuk kedalam kategori monopolistic competition. Bahkan nilai H-stat perbankan syariah ini cenderung mengarah kepada kondisi persaingan sempurna.

\section{Apakah kondisi perbankan syariah cukup Kompetitif?}

Sedikit mengulangi pemahaman yang baik tentang definisi contestable market; yaitu bentuk pasar yang didalamnya terdapat dominasi/penguasaan oleh satu atau sedikit pelaku industri terhadap pasar namun tidak menutup pelaku industri baru yang potensial. 
Hal ini dapat diistilahkan dengan tidak adanya barrier to entry bagi pemain baru yang dibentuk yang disebabkan oleh biaya, kebijakan maupun teknologi. Pasar yang ada walaupun didominasi oleh satu perusahaan saja tetap menjadi bentuk pasar yang kompetitif.

Tidak terdapatnya barrier to entry merupakan salah satu ciri dari persaingan sempurna. Selain itu ciri lain dari pasar persaingan sempurna ialah homogenitas produk (kesamaan produk). Homogenitas produk ialah produk yang memberikan kepuasan yang sama kepada konsumen tanpa melihat siapa yang memproduksi. Salah satu input yang diperlukan oleh bank untuk mendapatkan keuntungan ialah dana pihak ketiga salah (co: deposito). Bank harus menciptakan produk yang diinginkan oleh konsumen. Preferensi konsumen dalam memilih bank syariah dapat dilihat pada tabel dibawah ini:

Tabel 1.6

Alasan Konsumen Memilih Bank Syariah

\begin{tabular}{|c|c|c|c|c|c|c|c|c|c|}
\hline No & Alasan* & Total & $\begin{array}{l}\text { Muamal } \\
\text { at }\end{array}$ & $\begin{array}{l}\text { Syariah } \\
\text { Mandiri }\end{array}$ & $\begin{array}{c}\text { BRI } \\
\text { Syariah }\end{array}$ & $\begin{array}{c}\text { BNI } \\
\text { Syariah }\end{array}$ & $\begin{array}{l}\text { Bukopin } \\
\text { Syariah }\end{array}$ & $\begin{array}{l}\text { Permata } \\
\text { Syariah }\end{array}$ & Lainnya \\
\hline 1 & $\begin{array}{l}\text { Kesesuaian dengan } \\
\text { syariat Islam }\end{array}$ & 48.9 & 46.9 & 52.2 & 53.3 & 52.7 & 36.5 & 51.2 & 46.2 \\
\hline 2 & $\begin{array}{l}\text { Terhindar dari } \\
\text { sistem riba }\end{array}$ & 37.9 & 42.5 & 41.3 & 24 & 41.9 & 21.2 & 27.9 & 61.5 \\
\hline 3 & Aman & 16.3 & 15.5 & 22.5 & 12 & 16.2 & 9.6 & 11.6 & 23.1 \\
\hline 4 & $\begin{array}{l}\text { Lokasi bank dekat } \\
\text { dengan kantor }\end{array}$ & 12.7 & 14.5 & 13 & 4 & 6.8 & 21.2 & 20.9 & 7.7 \\
\hline 5 & $\begin{array}{l}\text { Bagi hasilnya } \\
\text { tinggi }\end{array}$ & 12.5 & 11.1 & 12.3 & 8 & 12.2 & 13.5 & 25.6 & 15.4 \\
\hline 6 & $\begin{array}{l}\text { Pelayanannya } \\
\text { memuaskan }\end{array}$ & 10.9 & 6.3 & 12.3 & 10.7 & 24.3 & 7.7 & 16.3 & $\mathrm{O}$ \\
\hline 7 & Payroll & 9.4 & 11.1 & 8 & 13.3 & 8.1 & 11.5 & o & 7.7 \\
\hline 8 & Ada fasilitas ATM & 8.3 & 6.3 & 11.6 & 8 & 10.8 & 7.7 & $\mathrm{O}$ & 15.4 \\
\hline 9 & Transfer gaji & 7.5 & 6.3 & 3.6 & 16 & 10.8 & 9.6 & $\mathrm{O}$ & 11.5 \\
\hline 10 & Dari kantor & 6.3 & 12.1 & 4.3 & 6.7 & $\mathrm{O}$ & 5.8 & o & O \\
\hline 11 & $\begin{array}{l}\text { Lokasi bank dekat } \\
\text { dengan rumah }\end{array}$ & 5.9 & 3.9 & 8 & 4 & 9.5 & 5.8 & 7 & 3.8 \\
\hline 12 & $\begin{array}{l}\text { Customer } \\
\text { servicenya ramah }\end{array}$ & 3.9 & 3.9 & 5.8 & 1.3 & 2.7 & 1.9 & 9.3 & O \\
\hline 13 & $\begin{array}{l}\text { Memiliki jaringan } \\
\text { ATM bersama }\end{array}$ & 3.3 & 3.9 & 3.6 & 1.3 & 5.4 & $\mathrm{O}$ & $\mathrm{O}$ & 7.7 \\
\hline 14 & $\begin{array}{l}\text { Ada fasilitas } \\
\text { umrah haji }\end{array}$ & 1.3 & 0.5 & 2.9 & 1.3 & $\mathrm{O}$ & 1.9 & 2.3 & $\mathrm{O}$ \\
\hline 15 & $\begin{array}{l}\text { Administrasinya } \\
\text { lebih murah }\end{array}$ & 1 & 1 & O & 1.3 & 2.7 & O & 2.3 & $\mathrm{O}$ \\
\hline \multirow[t]{2}{*}{16} & Lainnya & 3.2 & 2 & 5.6 & 2.6 & 1.4 & 3.8 & 2.3 & 3.8 \\
\hline & Total & 189.1 & 187.4 & 207.2 & 168 & 205.4 & 157.7 & 176.7 & 203.8 \\
\hline
\end{tabular}

Sumber : Survey Mars Indonesia(2008)

*Boleh memilih lebih dari satu alasan 
Berdasarkan tabel diatas dapat diketahui bahwa terdapat 16 faktor yang menjadi preferensi(alasan) nasabah untuk menyimpan dana yang dimiliki pada Bank Syariah. Dari keenam belas faktor itu terdapat lima faktor peringkat atas yang mendasari nasabah menggunakan bank syariah antara lain: sesuai syariat, terhindar dari sistem riba, aman, lokasi dekat kantor, dan bagi hasilnya tinggi. Terlihat dari hasil survei yang menjadi 2 alasan utama (yang menduduki peringkat atas) nasabah memilih bank syariah adalah karena faktor emosional. Hal ini tercermin dari dua alasan terbesar nasabah (sebesar 86,8 persen) menyimpan dananya di bank syariah karena bank syariah sesuai dengan syariat Islam, dan dapat terhindar dari riba, sementara sisanya merupakan faktor yang bersifat fungsional. Sealey (1977) mengatakan:

“ The depository financial firm's output in a technical sense is thus a set of financial services to the firm's depositors (creditors) and borrowers"

Berdasarkan pernyataan itu dapat dipahami bahwa fungsi dari lembaga keuangan (bank) ialah memberikan sejumlah jasa pelayanan keuangan. Dalam pandangan intermediation approach ada tiga faktor input dalam industri keuangan yaitu; tenaga kerja, modal fisik dan deposito untuk menghasilkan output(keuntungan). Untuk mendapatkan deposito (dana pihak ketiga) maka perusahaan keuangan harus memenuhi keinginan konsumen berupa “ jasa layanan keuangan”.
Berdasarkan tabel diatas dapat dijelaskan bahwa nasabah perbankan syariah lebih merupakan nasabah yang mengedepankan nilai-nilai emosional yang berfokus pada keuntungan emosional. Dalam pendekatan struktur pasar hal ini menunjukkan bahwa produk layanan ("nilai manfaat") antara satu bank syariah yang satu (misal: Bank Muamalat dengan Bank Syariah Mandiri) dengan bank syariah lainnya merupakan produk yang identik (homogenus) karena samasama mempunyai nilai sesuai dengan syariat, memberikan kepuasan yang sama. Ketika konsumen menganggap barang yang diproduksi (jasalayanan) mempunyai bentuk yang sama, maka terdapat bentuk subtitusi langsung terhadap suatu produk. Hal ini mengakibatkan biaya untuk masuk pasar tidaklah besar, karena konsumen tidak mengutamakan tuntutan bentuk fisik dari layanan (kantor cabang, atm dll). cukup sebuah industri perbankan dapat membuktikan bahwa produknya sesuai syariat.

Persaingan di industri perbankan syariah diuntungkan dengan kondisi nasabah yang tidak mengedepankan aspek fungsional bank yang berupa tampilan fisik antara lain tersedianya ATM, faktor lokasi,banyaknya cabang atau pelayanan yang ramah. Ketika sebuah bank dapat membuktikan dirinya "sesuai syariat" maka pasar perbankan syariah dapat disebut sebagai pasar yang contestable karena tidak terdapatnya barrier to entry ke pasar berupa teknologi atau kebijakan. Dalam 
kasus perbankan syariah derajat contestability lebih tinggi karena produk bank ("layanan simpanan") menjadi komoditi yang homogen sehingga persaingan cenderung menjadi lebih sempurna. Sebuah pasar disebut contestable maket jika biaya dari bank yang masuk industri sama dengan biaya dari bank yang dominan. Meskipun beberapa bank terbesar mendominasi pasar namun tetap memperoleh normal profit seperti bank yang lebih kecil.

\section{KESIMPULAN DAN SARAN}

\section{Kesimpulan}

Berdasarkan hasil penelitian diatas diketahui terdapat kompetisi antar bank syariah di industrinya meskipun dengan metode penghitungan concentration ratio dan HHI kondisi industri perbankan syariah dalam kondisi high concentration. Diketahui nilai $H$-stat untuk perbankan syariah adalah 0.737046, hal ini menggambarkan pasar dalam kondisi monopolistic competition. Nilai $\mathrm{H}$ stat ini memiliki kecenderungan mendekati kondisi pasar persaingan sempurna (mendekati nilai 1). Jika dilihat secara spesifik sumbangan terbesar nilai $\mathrm{H}$-stat berasal dari variabel beban personil yaitu sebesar 48,05 persen. Sedangkan sumbangan terbesar kedua berasal dari variabel beban bunga (bagi hasil) yaitu sebesar 25,64 persen.

\section{Saran}

Untuk perbankan syariah kebutuhan Sumber Daya Manusia (SDM) merupakan faktor yang perlu dipenuhi dalam meningkatkan pendapatannya karena sifat SDM di industri Perbankan Syariah mempunyai sifat yang unik.

Hendaknya perbankan syariah memfokuskan pembiayaan terhadap kegiatan yang berbasiskan pada akad musyarakah dan mudharabah, karena pada akad itulah tercermin keadilan dari ekonomi Islam.

\section{DAFTAR PUSTAKA}

A. Karim. Adiwarman. 2004. Bank Islam-Analisis Fiqih dan Keuangan. Cet.4. Jakarta: PT Rajagrafindo Persada.

Andriansyah, Yuli. 2009. "Kinerja Keuangan Perbankan Syariah di Indonesia dan Kontribusinya bagi Pembangunan Nasional”,Jurnal Ekonomi Islam La Riba.3.

Ariss. Rima Turk. 2010. "Competitive conditions in Islamic and conventional banking: A global perspective". Review of Financial Economics, 19:101-108.

Ariyanto, T. 2004. "Profil Persaingan Usaha Dalam Industri Perbankan Indonesia".Perbanas Finance and Banking Journal. 6: 95-108. 
Baltagi, B. H. 2001. Econometric Analysis of Panel Data.2 $2^{\text {nd }}$ edition. Chichester: Wiley \& Sons.

Bank Indonesia. 2012. Laporan Keuangan Publikasi Bank Indonesia-wrwr.bi.go.id. Jakarta.

Bikker, Jacob A., dan Katharina Haaf. 2002. "Competition, concentration, dan their relationship: An empirical analysis of the banking industry”.Journal of Banking and Finance. 26: 2191-22 14.

Chapra, M. Umar. 2000. "Is it necessary to have Islamic economics?". Journal of Socio-Economics. 29:2137.

De Bandt, O., dan Davis, E.P., 2000. "Competition, contestability and market structure in European banking sectors on the eve of EMU”. Journal of Banking and Finance, 24:1045-1066

Gilbert, Alton R. B. 1984. "Bank Market Structure and Competition: A Survey”.Journal of Money, Credit and Banking.16:617-660.

Gujarati, Damodar. 1995. Basic Econometrics, $3^{\text {rd }}$ Edition. New York: Mc Graw Hill. Inc.

Hasan, M. Iqbal. 2000. Pokok-Pokok Materi Statistik 2 (Statistik Inferensi). Cet. 2. Jakarta: Bumi Aksara

Mars Indonesia. 2008. Studi Pasar dan Perilaku Nasabah Bank Syariah. Jakarta. h.109.

Martin, Stephen. 1988. Industrial Economic - Economic Analysis and Public Policy. $2^{\text {nd }}$ Edition, New York: Macmillan Publishing Company.

Sancoko.2009. "Analisa Perbandingan Konsentrasi antara Perbankan Syariah dan Perbankan Konvensional".Jurnal Administrasi Terapan,Vol. X(1)

Sealey, Jr.C.W., and Lindley, J.T. 1977. "Input, output and a theory of production and cost at depository financial institution". Journal of Finance 4, $1251-1266$.

Syafii, Muhammad Antonio. 2001. Bank Syariah dari Teori ke Praktik. Cet.17. Jakarta: Gema Insani Pers.

Swastanto, Joni. 2007. Analisis kemampuan perolehan laba Bank dan implikasinya terhadap konsulidasi perbankan Indonesia. Disertasi. Universitas Indonesia.

Weill, Laurent. 2009. "Do Islamic Banks Have Greater Market Power?".Laboratoire de Recherche en Gestion \& Economic Working Paper 2009-02

Wibisono, Yusuf. 2009. "Politik Ekonomi UU Perbankan Syariah Peluang Dan Tantangan Regulasi Industri Perbankan Syariah”.Bisnis \& Birokrasi, Jurnal Ilmu Administrasi Dan Organisasi.16: 105-115. 